\title{
The Development of Learning Tools Based on SETS with Interactive Multimedia to Improve Science Learning Outcomes
}

\author{
F.S. Setiawan, Mustaji, W. Widodo \\ Universitas Negeri Surabaya \\ Surabaya, Indonesia \\ fajarsidiqsetiawan@gmail.com
}

\begin{abstract}
The purpose of this research is to produce a learning tool based on SETS with interactive multimedia to improve science learning outcomes. Feasibility is seen from the results of validation, practicality, and effectiveness. This research uses Dick and Carey model with Pretest-Posttest One Group Design. Data were collected through observation method, interview, validation, questionnaire, and test. The data analysis technique used quantitative and qualitative descriptive analysis. The results show that the developed learning tools are valid; students show a positive response to the learning process; the score of learning outcomes from the knowledge aspect increased from an average of 40 to 82 with high N-gain categories. Meanwhile, the average score of attitudinal aspects in good categories and the average score of skills aspect was 79. Therefore, it can be concluded that learning tool based on SETS with interactive multimedia is feasible to improve students' science learning outcomes.
\end{abstract}

\section{Keywords-Interactive Multimedia}

\section{INTRODUCTION}

Science and technology globally are constantly evolving. It can be seen and felt in everyday life in the environment. To that end, educating the generation that mastered science and technology is necessary to be able to balance the rate of development of science and technology. As stated in Permendikbud No. 21 the year 2016, science teaching in elementary school is intended to recognize, respond to, and appreciate science and technology, and to inculcate critical thinking habits and scientific behavior, creative and independent. This is in line with Carin (1993: 31) stated that basically one of the goals of science taught in schools is to develop students' understanding and attitudes about nature, limitations, and possibilities arising from science and technology, so that students can: (1) Acknowledge and apply knowledge, attitudes and thinking habits; (2) increasing students' understanding of science and technology; (3) become more aware of the interaction of science and technology with society; (4) using science knowledge and technology, attitudes, and decision-making skills. Thus, it needs to provide learning tools that can support the achievement of expected learning objectives, especially in science learning.

Based on interviews with teachers at Bogor District, West Java, there are several problems that occur in science learning. The problem includes the incompatibility of learning models and the media used with the characteristics of the material to be taught and the difficulties of students in understanding some of the learning materials of science so that the learning achievement is less than optimal. One example is the learning material of the water cycle and its impact on earth events and the survival of living things. Teachers must choose appropriate learning and media models to teach this material because the characteristics of this material are difficult to understand if the learning process is limited to theoretical explanations and not applied directly in life. If the learning model and the media used are not accurate, it will affect the learning outcomes of science in every elementary school, especially the learning outcomes in the learning materials of the water cycle and its impact on earth events and the survival of living things. In addition to the use of learning models and media that are less precise with the characteristics of the material to be taught, the other cause is the students' low motivation learning.

The motivation of students to learn is very influential in the learning process because someone who does not have motivation in learning will not be possible to do learning activities. According to Sardiman (2007: 75) students who are not motivated in learning, learning efforts tend to be less systematic than students who are motivated to learn, so it is likely to affect learning outcomes. Learning outcomes represent attainment of behavioral changes that tend to settle from the cognitive, affective, and psychomotor aspects of the learning process done within a certain time (Jihad \& Haris, 2013: 14). Therefore, it is a necessary model of learning and media that can improve student's motivation in learning, so as to optimize the learning result of science. Appropriate learning model to teach the material of the water cycle and its impact on earth events and the survival of living things is the learning model of Science Environment Technology and Society with interactive multimedia.

The reason why it needs Science Environment Technology and Society (SETS) learning model with interactive multimedia is because this instructional model is more emphasized on the active participation of students, and able to package the concept of science to be applied with the problems of everyday life. This is reinforced by the opinion of Sutarno (2009: 9.31) that SETS learning model could lead student to increase their ability to think critically and sensitively to environmental problems, technological developments, and society. Moreover, students also can play an active role to find solutions. Students 
activities in the form of exercise so that students can experience it directly. Abstract science lessons, difficult and tedious, will be interesting and meaningful lessons so that learning motivation is on the rise and students become easy to understand concepts [15]. The advantages of the Science SETS learning model are: (a) students can apply knowledge, knowledge and accustomed to thinking; (b) it increases students' understanding of science and technology; (c) students become more aware of the interaction of science and technology with society; (d) students can use science and technology knowledge, attitudes, and decision-making skills. Also, the use of interactive multimedia aims to facilitate some explanation of the abstract concept and process in accordance with the characteristics of the material being taught. The usefulness of using interactive multimedia in learning in accordance with Munir (2012: 113-114) are: (a) a more innovative and interactive learning system; (b) may combine text, images, audio, music, image animations or videos in a mutually supportive whole to achieve the learning objectives; (c) increase student motivation during the learning process until the desired learning objectives are obtained; (d) be able to visualize difficult material explained by conventional explanations or props; (e) train students to be more independent in gaining knowledge. Therefore, the use of Science Environment Technology and Society learning model with interactive multimedia can provide an interesting and meaningful experience for students, to improve the learning outcomes of science.

According to a study conducted by Yörük, N., et al. (2010), the use of science, technology, society, environment (STSE) learning model can significantly improve students' understanding. Osman \& Lee. (2014) also states that there is a significant positive influence on the use of interactive multimedia with learning motivation and student understanding. This means that there is a significant positive influence on the use of Science Environment Technology Society learning model and interactive multimedia with science learning outcomes.

Based on these assumptions, this research focuses on the development of learning tools based on Science Environment Technology and Society with interactive multimedia to improve the learning outcomes of science on students of Elementary School. Learning tools are the tools used in the teaching and learning process. Each teacher is in charge of developing learning tools that are interactive, inspiring, fun and motivating students to participate actively. Learning tools are designed in the form of Syllabus and Learning Implementation Plan which refers to the Content Standards. Lesson planning includes preparation of learning implementation plan, preparation of student textbook, media, student worksheet, and learning evaluation tool.

\section{METHODS}

This is a developmental research which develop learning tools based on Science Environment Technology and Society with interactive multimedia using Dick and Carey model (2015: 1). The Dick and Carey model research design is shown in Figure 1:

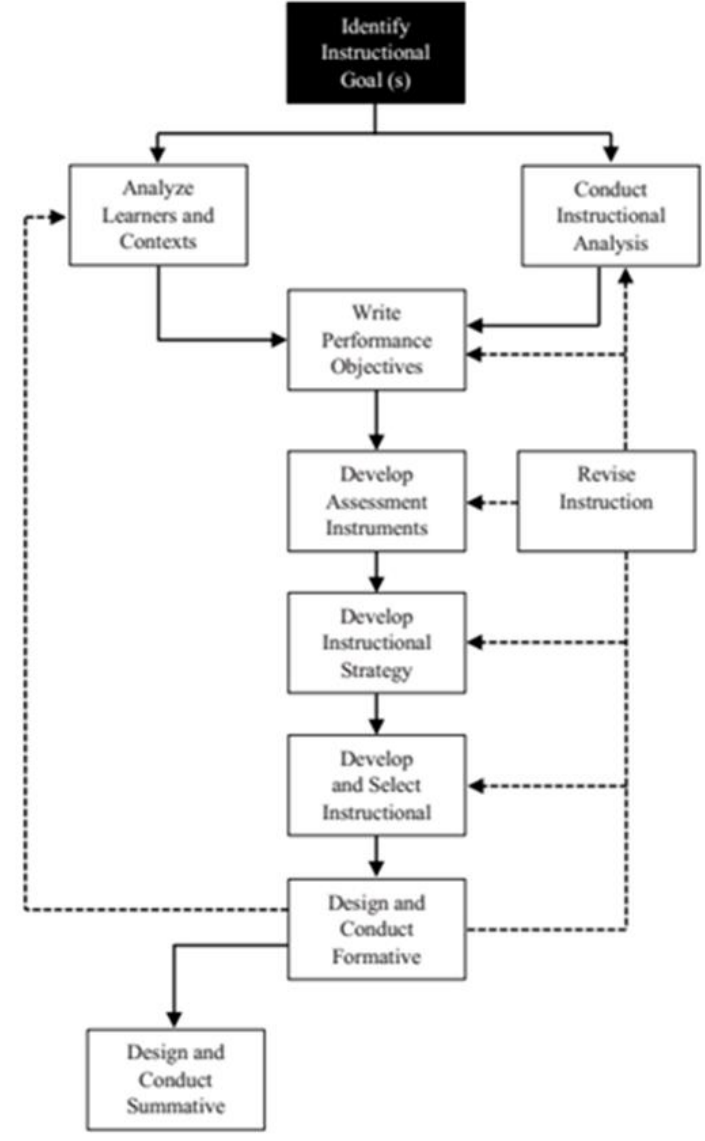

Figure I. DICK AND CAREY MODEL RESEARCH DESIGN

In this study, data collection methods used observations, interviews, expert judgment, questionnaires, and tests. The instrument used is the learning tool validation sheet, the observation sheet of learning implementation, student activity observation sheets, student response questionnaires, and assessment tools of science learning outcomes.

Learning tool validation results were descriptively analyzed by calculating the average score of the validation. Average scores were converted using criteria for categorization of validity and learning tools (Ratumanan \& Laurens, 2011: 34). The science learning outcomes were analyzed using $\mathrm{N}$-gain or gain score, the sensitivity of the evaluation items, and the completeness of the learning outcomes of science.

\section{RESULTS AND DISCUSSION}

A learning tool is considered feasible to be used in the learning process if it meets the quality aspects of validity, practicality, and effectiveness (Richey and Nelson in Rahman, 2013: 207).

The validation result of Learning Tools on Science Environment Technology and Society with interactive multimedia as shown in Table 1: 
TABLE I. VALIDATION RESULT

\begin{tabular}{|c|l|c|c|}
\hline No & \multicolumn{1}{|c|}{ Component } & Score & Category \\
\hline 1 & Syllabus & 3,50 & Valid \\
\hline 2 & Learning Implementation Plan & 3,60 & Valid \\
\hline 3 & Student worksheet & 3,65 & Valid \\
\hline 4 & Student textbook & 3,50 & Valid \\
\hline 5 & Media & 3,50 & Valid \\
\hline 6 & Learning appraisal tool & 3,30 & Valid \\
\hline \multicolumn{2}{|c|}{ Average Score } & 3,50 & Valid \\
\hline
\end{tabular}

In Table 1, the average tools validation score developed is 3.50. According to Ratumanan \& Laurens (2011: 34) validation results were categorized valid because the validation score is in between 2.6 and 3.5. This indicates that instructional tools based on Science Environment Technology and Society with multimedia interactive can be used in learning.

To know the practicality of learning tool developed, the researcher observed the students' activity during the learning by using observation sheet. The observation of results shows that learning took place in accordance with the lesson plan well. Observation results of student activity during the learning is shown in Figure 2:

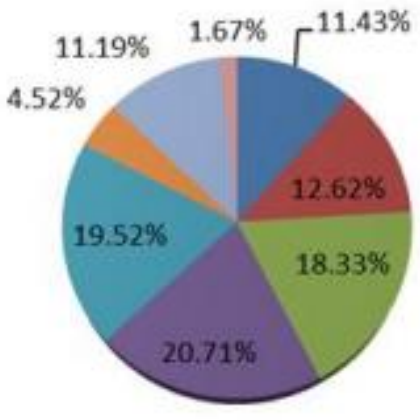

= Activity 1
= Activity 2
$=$ Activity 3
$=$ Activity 4
$=$ Activity 5
$=$ Activity 6
$=$ Activity 7
$=$ Activity 8

Figure 2 Student activity

Figure 1 shows that the activities undertaken by students during the learning: (1) Listening to teacher explanation $11.43 \%$; (2) Operating or viewing interactive multimedia show $12.62 \%$; (3) Asking questions 18.33\%; (4) Expressing opinions on problem $20.71 \%$; (5) having group discussion $19.52 \%$; (6) doing presentation of group work $4.52 \%$; (7) completing an independent evaluation 11.19\%; and (8) doing irrelevant behavior $1.67 \%$. Based on the above explanation, the most often performed is expressing opinions relevant to student centered issues and learning. This is in line with the main goal of Science Environment Technology and Society learning model that encourages stu-dents to take an active role in solving problems by applying the concept of science in everyday life.

Furthermore, the effectiveness of this learning tool is seen from the results of student responses and learning outcomes of science. Student response data were obtained by using the questionnaire given after the learning process was completed. The results of the response questionnaire as shown in Table 2:

\section{TABLE II. RESPONSE QUESTIONNAIRE RESULTS}

\begin{tabular}{|c|c|c|}
\hline No & Description & $(\%)$ \\
\hline 1 & Students are attracted to the advocacy process & 99 \\
\hline 2 & Students feel new to the learning to process & 97 \\
\hline 3 & Students feel good about the learning & 98 \\
\hline 4 & Students find it easy to follow the learners & 92 \\
\hline 5 & $\begin{array}{l}\text { Students are interested to follow the learning activities } \\
\text { that have been done on the next lesson }\end{array}$ & 100 \\
\hline \multicolumn{2}{|r|}{ Avrage Score } & 97 \\
\hline
\end{tabular}

In Table 2, It can be seen that students give a very positive response that is equal to $97 \%$. This means that the learning based on Science Environment Technology and Society with interactive multimedia is interesting, a new learning model, fun, and easy to implement. The positive response given indicates that students are enthusiastic about the lessons. This can certainly motivate stu-dents to increase their attention and get them in-volved in a fun and meaningful learning experience, so that science learning outcomes increase.

Learning Tools Based on the Science Environ-ment Technology and Society with interactive multimedia also affect science learning outcomes from the knowledge aspect. The pretest average value before the treatment is still below the standard score and after using that learning tool the posttest average value increased to 82 and thus all students were declared passed the minimum standard score (70). Based on NGain analysis, the difference between pretest value and posttest value in the high category. Evaluation tool used as science learning result test on knowledge aspect has also analyzed the level of sensitivity. Ibrahim (2005: 49) said that sensitivity is the ability of an evaluation tool to measure the effect of learning, in other words, the evaluation tool is said to be sensitive if it can give information that the results of the evaluation obtained are the result of the learning process undertaken. The results sensitivity analysis of the evaluation tool are categorized as sensitive with an average value of 0.6 , so it can be interpreted that the evaluation tool is in a good category. In addition to learning outcomes in the aspects of knowledge, attitude and skills aspects were also assessed for the value of science learning outcomes. Science learning outcomes on attitude aspect average 3.00 with the good category. While for the skill aspect, the average score is 79 and all students are stated pass because they get the value of $\geq 70$. So, based on the analysis of science learning outcome assessment from the aspect of knowledge, attitude, and skill, all the students passed on learning the material of the water cycle and its impact on earth events and the survival of living things.

The difference between learning tools based on Environmental Science Technology and Society with interactive multimedia and other learning tools lies in the learning steps and media used [14] where the learning steps adapted to the syntax of learning model of Science 
Environment Technology and Society and combined with the use of interactive multimedia. It ranges from initiation or invitation, concept formation, concept application, concept consolidation, and assessment, so that the material presented interesting, fun, easy to understand and can be applied in everyday life. Initial activity begins with preliminary activities by praying together, preparing the condition of the students before carrying out the learning activities, checking the attendance of students and doing apperception by question and answer with students about the material to be learned on that day. The activity aims to determine the student's early ability. Followed by reading out the purpose of learning and give motivation to students. The core activities are carried out with interactive multimedia by initiation or invitation with video playback containing issues or questions to be discussed. This activity aims to give stimuli to students to focus and explore the knowledge that students have about the issue issues to be solved. After that, students are encouraged to proceed with the development of the concept with the group to find more information either through observation, experiment, reading the teaching materials, discussions, work on student worksheets or play interactive multimedia. The next activity is a concept application that aims to apply concepts that have been learned in everyday life. The next activity is the consolidation of the concept that students do by paying attention to the explanations or feedback given by the teacher. After the consolidation of the concept, the last activity is the assessment, the students do the evaluation test at the end of the learning.

From the results of research, there is a relationship between the validation of learning tools, the implementation of learning, student activity with motivation and science learning outcomes. The results of the validity of learning tools by experts who then used the teacher in learning can affect the implementation of learning and student activities. This is in accordance with the theory of modeling by Bandura and Joyce \& Weil which presents five important elements as a description of a lesson, namely (1) syntax, which is a sequence of activities commonly called phase, (2) social system, the role of teachers and students and the types of rules needed in learning, (3) the principle of reaction, which gives the teacher a picture of how to view or respond to student questions, (4) support systems, ie conditions required, and (5) instructional and accompanist impacts.

Based on the description above, the development of learning tools based on Science Environment Technology and Society with interactive multimedia as a whole has met the criteria of a decent learning tool to improve science learning outcomes.

\section{CONCLUSION}

Based on the results of research that has been done, it can be concluded that: (1) Learning tools based on Science Environment Technology and Society with interactive multimedia that developed is feasible and can be used in learning; (2) Students respond positively to application of Science Environment Technology and Society learning model with interactive multimedia; (3) Students' science learning outcomes were improved after applying learning tools based on Science Environment Technology and Society with interactive multimedia.

\section{REFERENCES}

[1] Carin, A.A. 1993. Teaching Modern Science. New York: Macmillan.

[2] Dick, Walter., Carey, Lou., \& Carey, James O. (2015). The Systematic Design of Instruction. United States of America: Pearson.

[3] Ibrahim, M. 2005. Asesmen Berkelanjutan Konsep Dasar, Tahapan Pengembangan, dan Contoh. Surabaya: Unesa University Press.

[4] Jihad, Asep \& Haris, Abdul. 2013. Evaluasi Pembelajaran. Yogyakarta: Multi Presindo.

[5] Kemdikbud. 2016. Permendikbud Nomor 21 Tahun 2016 tentang Standar Isi. Jakarta: Kemdikbud.

[6] Munir. 2012. Multimedia Konsep dan Aplikasi dalam Pendidikan. Bandung: Alfabeta.

[7] Ormrod, J. E., 2008. Educational psycology developing (6th ed) (Terjemahan Penerbit Erlangga). Jakarta: Gelora Aksara Pratama.

[8] Osman, Kamisah., \& Lee, Tien Tien. 2014. Impact of Interactive Multimedia Module with Pedagogical Agents on Students Understanding and Motivation in the Learning of Electrochemistry. International Journal of Science and Mathematics Education. Volume 12, Issue 2, pp 395-421.

[9] Rahman, Muhamad. \& Sofan, Amri. 2013. Strategi \& Desain Pengembangan Sistem Pembelajaran. Jakarta: Prestasi Pustaka.

[10] Ratumanan, T. G., \& Laurens, T. 2011. Penilaian Hasil Belajar Pada Tingkat Satuan Pendidikan Edisi 2. Surabaya: Unesa University Press.

[11] Sardiman, A.M. 2007. Interaksi dan Motivasi Belajar Mengajar. Bandung: Rajawali Pers.

[12] Sutarno, N. 2009. Materi dan Pembelajaran IPA SD. Jakarta: Universitas Terbuka.

[13] Yoruk, N., Morgil, I., \& Seçken, N. 2010. The Effect of Science, Technology, Society, Environment (STSE) Interaction on Teaching Chemistry. Natural Science, Vol. 2, No. 12, 1417-1424.

[14] Walmsley, B. (2003). Partnership-Centered Learning: The Case For Pedagogic Balance In Technology Education.

[15] Mislevy, R. J., \& Durán, R. P. (2014). A sociocognitive perspective on assessing EL students in the age of Common Core and Next Generation Science Standards. TESOL Quarterly, 48(3), 560-585. 